\title{
China's International Strategy and How to Pursue It
}

\author{
Chairul Aftah \\ Jurusan Ilmu Hubungan Internasional, Fakultas Ilmu Sosial dan Ilmu Politik, \\ Universitas Mulawarman
}

\begin{abstract}
China is a major actor in the Asia Pacific region and global because of its economy, politic, military, social and cultural capabilities. In world history, this position has been built through several stages. In the PostWorld War II, China was considered dangerous despite its inability to show diplomatic influence in international relations, especially with the United States and its allies. It was only after 1980, after Deng Xiaoping came to power, China began to increase their influence through a variety of domestic and international policies. As a result, China's existence has been increasingly recognized in various fields. Domestically, China considers that the increase of its multisectoral capability as an effort to put China on an equal footing with other actors that have better capabilities. In contrast, for the other states, the increase of China's ability has been perceived as a threat because it raised China's bargaining power. Thus, it is crucial for China to convince others that its progress is not a threat. In improving its capabilities, China formulated an international strategy in both regional and international level. Therefore, China sought to implement these strategies by improving its relationship with other actors.
\end{abstract}

Keywords: China, international strategy, peaceful rise

\begin{abstract}
Abstrak
Tiongkok merupakan salah satu aktor utama di Asia Pasifik dan global karena kapabilitas ekonomi, politik, militer, sosial dan budaya yang dimilikinya. Dalam sejarah dunia, posisi tersebut telah dibangun dalam berbagai tahapan. Pada pasca Perang Dunia II, Tiongkok dianggap berbahaya bagi dunia meskipun negara ini belum mampu menunjukkan eksistensi diplomatiknya di dalam hubungan internasional terutama dengan Amerika Serikat dan sekutunya. Barulah pada pasca 1980an, setelah Deng Xiao Ping berkuasa, Tiongkok mulai meningkatkan pengaruhnya melalui berbagai kebijakan domestik dan internasional. Akibatnya, eksistensi Tiongkok semakin diakui di berbagai bidang. Secara domestik, Tiongkok menganggap bahwa peningkatan kapabilitas multisektornya sebagai usaha untuk mensejajarakan diri dengan aktor lain yang kapabilitasnya lebih baik. Sebaliknya bagi aktor lain, peningkatan kemampuan ini merupakan ancaman karena meningkatnya daya menawar Tiongkok. Menjadi penting bagi Tiongkok untuk meyakinkan bahwa kemajuan yang dimilikinya bukanlah sebuah ancaman bagi pihak lainnya. Dalam meningkatkan kapabilitasnya, Tiongkok merumuskan strategi politik baik di level regional maupun internasional. Oleh karena itu, Tiongkok berupaya mengimplementasikan strategi tersebut dengan meningkatkan hubungannya dengan actor-aktor lain.
\end{abstract}

Kata kunci: Tiongkok, strategi internasional, peaceful rise 
In post-Cold War world, China plays critical role in world politics. China is involved in almost all global issues ranging from climate change, humanitarian to the Nuclear NonProliferation Treaty. In addition, China is a country that has the highest economic growth in the world which seeks to open good relations with all countries. China offers a huge market and profitable investment because of its large population and industrialization. Meanwhile at the same time, it is considered as a threat to the other countries.

This essay argues that China's formulates its international strategy to pursue a great power status in world politics. This requires the country to improve not only in terms of material capability but also social leadership. Therefore, international strategy becomes important and interesting to be observed. It is important for China to be a great power that can influence others rather than simply posing threats.

When Deng Xiao Ping was in power, he attempted to do buyaodangtau concept (not trying to be a leader). He avoid any global ambition. Mostly, Deng did this because China has not been able to bear any global responsibility yet. But in his successor's period, China has been increasing its role in wider arena (Yunling and Shibling, 2005: 48). As one of the major actors, China increasingly accepted its global responsibilities in international relations. China is involved in a lot of institutions and activities across countries. In climate change negotiations, China is currently considering to be more measureable, reportable, and clear in verifying targets for emissions and China also uses its leverage to forge a consensus for an international climate framework at Copenhagen 2009 (U.S. legislation to reduce carbon is also necessary) (Hachigian, 2009: 5). In global economic initiatives, China rebalances the global economy by continuing to move to a more domestic-led growth model, and ensure that is a successful forum (Hachigian, 2009: 5). In the nuclear nonproliferation negotiations, China becomes a constructive, proactive and dedicated player in the Iran and North Korea talks (Hachigian, 2009: 5). China also supports the enactment and implementation of, the Comprehensive Nuclear Test Ban Treaty, the Non-Proliferation Treaty and the Fissile Material Cutoff Treaty (Hachigian, 2009: 5). In pandemic prevention efforts, China takes the lead to reform World Health Organization (Hachigian, 2009: 5). China also demonstrates its conformity to international standard by producing vaccines that meet U.N. agencies standards foe use. (Hachigian: 2009)

This essay is divided into five sections. The first part is an introduction. The second part is discussing about international strategy. The third part explains about China strategy. The fourth part is how China pursues its international strategy. The fifth part is conclusion.

\section{International Strategy}

Grand strategy is a concept that refers to its scope rather than its nature. Therefore, the concept is formulated by considering several aspects of state activities. It is labeled as 'grand' because it refers to overarching vision of state leaders in combining the broad range of capabilities linked with military, economic, and diplomatic strategies to pursue their international goals (Goldstein, 2005: 19). Grand strategy refers to how a state coordinates their policies in several domains for reducing difficult work at cross-purposes. Grand strategy not only refers to comprehensive description of state various foreign policies. It also refers to the central logic that informs links between policies, the regime vision about national's interest (goals), in light of country's capabilities (means), and international constraints it faces (the context of interdependent choice) (Goldstein, 2005: 19).

China international strategy is peaceful rise. Essentially, China does not seek hegemony or predominance in world politics. It suggests that new international political and economic order can be achieved by the incremental reforms. China provides much attention on democracy and peace in international world system because its development depends on world peace that its development will turn reinforce (Bijian, 2005: 24). 


\section{China's Strategy}

The most significant strategic choice the China has made was to embrace economic globalization rather than detach from it (Bijian, 2005:20). In the late 1970s, when the new technological revolution and a new wave of economic globalization were unfolding with great momentum, Beijing grasped the trend and reversed the erroneous practices of the Cultural Revolution (Bijian, 2005:20). On the basis of the judgment that China's development would depend on its place in an open world, Deng Xiaoping and other Chinese leaders decided to seize the historic opportunity and shift the focus of their work to economic development (Bijian, 2005:20). They carried out reforms meant to open up and foster domestic markets and tap into international ones (Bijian, 2005:20). They implemented the household contracting system in rural areas and opened up 14 coastal cities, thus ushering in a period of economic takeoff (Bijian, 2005: 20).

In the 1990s, China once again confronted a strategic choice, due to the Asian financial crisis and the subsequent struggle between the forces for and against globalization (Bijian, 2005:20). China's decision to participate in economic globalization was facing a serious challenge (Bijian, 2005:20). But by carefully weighing the advantages and disadvantages of economic openness and drawing lessons from recent history, Beijing decided to open up China even more, by joining the World Trade Organization and deepening economic reform at home (Bijian, 2005: 20).

China has based its modernization process mainly on its domestic resources (Bijian, 2005:20). It has relied on ideological and institutional innovations and on industrial restructuring (Bijian, 2005:20). By exploring the growing domestic market and transferring the huge personal savings of its citizens into investment, China has infused its economy with new momentum (Bijian, 2005:20). Its citizens' capacities are being upgraded and its technological progress expedited (Bijian, 2005:20). Even while attempting to learn and absorb useful products from other societies, including those of the advanced capitalist countries, China has maintained its independence and self-reliance (Bijian, 2005: 21).

In pursuing the goal of rising in peace, China's leadership in world economy has strived in improving China's relations with all the nations of the world (Bijian, 2005:21). Despite the ups and downs in U.S.-Chinese relations over the years, as well as other dramatic changes in international politics such as the collapse of the Soviet Union, Beijing has stuck to the belief that there are more opportunities than challenges for China in today's international environment (Bijian, 2005:21).

\section{China Pursues its International Strategy} Under peaceful rise strategy, China accelerates its economic capabilities in world economy. China's share in the world economy has slightly changed since Deng was in power. A key element of Deng Xiaoping's economic reform strategy is a shift from Maoist ideal of national self sufficiency to reaping gains available from participating in the world economy (C. Fred Bergsten, 2006: 73). The result has been an expansion of China's trade that has outpaced the growth of its domestic economy and far exceeded the growth of global trade over almost three decades. Since the reform was launched, China's export and import have grown tenfold. In 2004, China surpassed Japan as the world's third largest economy.

According to China's strategic plans, it will take another 45 years-until 2050-before it can be called a modernized, medium-level developed country (Bijian, 2005:21). China will face three big challenges before it gets there (Bijian, 2005:21). As described above, China's shortage of resources poses the first problem. The second is environmental: pollution, waste, and a low rate of recycling together present a major obstacle to sustainable development (Bijian, 2005:21). The third is a lack of coordination between economic and social development (Bijian, 2005: 21).

The world is now connected very closely. Globalization has opened channel of interactions between countries, regions, continents and peoples. This is especially true 
in terms of economic relations. There are opportunities and threats in the global economy to which China must adapt. If China refuses to adapt, it will miss the good prospects. Therefore, China requires reform in its economic policy.

The first strategy in the economic reform is to transcend the old model of industrialization and to advance a new one (Bijian, 2005:22). The old industrialization was characterized by rivalry for resources in bloody wars and by high investment, high consumption of energy, and high pollution (Bijian, 2005:22). Were China to follow this path, it would harm both others and itself (Bijian, 2005:22). China is instead determined to forge a new path of industrialization based on technology, economic efficiency, low consumption of natural resources relative to the size of its population, low environmental pollution, and the optimal allocation of human resources (Bijian, 2005:22). The China government is trying to find new ways of reducing the percentage of the country's imported energy sources and to rely more on China's own. The objective is to build a "society of thrift" (Bijian, 2005: 22).

In line with the economic reform, China also conducts a reform in its foreign politics strategy. China aware that it has to transcend the traditional ways for great powers to emerge, as well as the Cold War mentality that defined international relations along ideological lines (Bijian, 2005:22). China will not follow the path of Germany leading up to World War I or those of Germany and Japan leading up to World War II, when these countries violently plundered resources and pursued hegemony (Bijian, 2005:22). Neither will China follow the path of the great powers vying for global domination during the Cold War (Bijian, 2005:22). Instead, China will transcend ideological differences to strive for peace, development, and cooperation with all countries of the world (Bijian, 2005: 22).

Internally, China also employs a strategic reform. China transcends outdated modes of social control and tries to construct a more harmonious socialist society (Bijian, 2005:22). The functions of the Chinese government have been gradually transformed, with self-governance supplementing state administration (Bijian, 2005:22). China is strengthening its democratic institutions and the rule of law. It also tries to build a stable society based on a spiritual civilization (Bijian, 2005:22). This has been done together with a launching of a great number of ideological and moral-education programs (Bijian, 2005: 22).

Several dynamic forces are noticeable in the carrying out of the three level strategies (Bijian, 2005:22). For example, there are numerous clusters of vigorously developing cities in the coastal areas of eastern and southern China, and similar clusters are emerging in the central and western regions (Bijian, 2005:22). They constitute the main engines of growth, are the major manufacturing and trading centers, and absorb surplus rural labor (Bijian, 2005:22). They also have high productivity, advanced culture, and accumulated international experience that the rest of China can emulate and learn from (Bijian, 2005:23). The expansion of China's middle-income strata and the growing need for international markets come mainly from these regions (Bijian, 2005:23).

China enters the post-Cold War more securely than it was before. But it is also facing condemn and sanction from the US and its alliance, including Japan. The US-China relationship is fragile, although China is still maintaining their relationship. Even, when the US sold F16s to Taiwan in 2011, to some extent, it was regarded by China as an intervention to its domestic disputes. (Kompas, 7 September 2011) But on other side, the US 'hegemonic' gesture provides a legitimate excuse for China to be more firm and defensive. (Goodwin 1998: 30) For China, the US hegemony becomes a foundational driving for a more robust foreign policy in the post cold war. Therefore China has to adapt and anticipate all the circumstances.

In terms of this balancing course, China approaches regional and global security issues in several ways. First, China observed the changing role of alliances. The post-Cold War traditional alliances are contested because the countries sought new arrangements to promote stability, reduce uncertainty, establish communication, and confidencebuilding channels. In the post-Cold War era, 
the US alliance faces new challenges in Europe, Middle East, Persian Gulf and other regions. Meanwhile, China has been active in supporting other types of security mechanism, including ASEAN Regional Forum, Shanghai Cooperation Organization, ASEAN plus three and the East Asia Summit (Gill, 2007:11). Second, Chinese security concerns also relate to proliferations and arm control, particularly on proliferation of weapons of mass destruction and their delivery vehicles, especially nuclear weapons, ballistic missiles, and related technologies (Gill, 2007:11). China participates in several key agreements, such as Chemical Weapon Convention (1993), the Comprehensive Test Ban Treaty (1996), the indefinite extension of the Nuclear Nonproliferation Treaty (1995) (Gill, 2007:11). Through those key agreements, China is involved with the international community. Thus makes important steps in solidifying norms of arm control and non-proliferation (Gill, 2007: 11).

China's security approach obviously shows China's wealth and influence. More importantly, it convinces China's neighbors of China's peaceful intentions and mutual beneficial relationship. China's leaders promote the peaceful rise concept that has changed to peaceful development. Besides Chinese leader also maintain a stable international environment, so Beijing can focus on economy, politic and social change domestically. The 2002 Chinese Defense White Paper points out clearly: "A developing China needs a peaceful international environment and favorable climate in periphery. (China Information Office, 2008) In pursuing its security goals, China must play a defensive role and does not want US to see China as foe (Jisi, 2005: 39).

In international arena, China has more focus on Asia. This is because there are several major powers that have strategic interests in Asia, such as: the U.S., Russia, Japan and perhaps India. Therefore, Asia becomes more dynamic in the security realm. Among others sub regions in Asia, China gives special attention to Southeast Asia. This is driven by the geopolitical measures as China shares territorial borders with 3 Southeast Asian countries: Laos, Vietnam and Burma. China also joins some South Asia driven institutions such as the Asian Regional Forum (ARF) and the ASEAN +3. China also undertook the similar approach with South Asia, Northeast Asia, Central Asian states. China also forms a better relationship with Russia.

In the economic realm, China is a global player. This is indicated by increasing export to countries outside Asia. China economic partner are the US, Australia, and developing countries in Africa. China emphasizes to developing countries in Africa because of its energy needs. This particularly because China needs energy supply from developing countries In accordance with the opinion, China's energy needs has dictated its overall economic approaches to international arena. This particularly true in China's engagement with some Africans countries that have rich natural resources, such as Angola, Nigeria, South Africa, Zimbabwe, Malawi, Togo, Benin, Sudan and Tunisia. (Brookes and Sie, 2006)

In foreign policy realm, China is more supportive to global agenda. This is obvious when China decides to send its troop as part of the UN mission to maintain peace in Africa, for instance to Sudan in 2014 and Mali in 2013. In addition, China is also active in the multilateral cooperation, such as the United Nations, Asia Pacific Economic Cooperation and the World Trade Organization. China also builds bilateral cooperation with the U.S., Japan, Russia and the developing countries to maintain peace.

\section{Conclusion}

In pursuing the great power status, China has been aware that it is crucial to seek good relations with all parties. China would be more benefited if the other actors perceived it as a peaceful actor. This is an urgent political requirement for China to rise without provoking enmity in international arena. Through peaceful rise, China tries to convince others that its security, economy and foreign policies are not coercive to others. This is why China conducts a range of policy reforms at economic, socio-politics, and diplomatic sectors to establish channels of understanding and good relations. 
In Economic realm, as an emerging power, China shows that its economic development cannot perform well without other parties. So, China convinces other countries that China does not pose threat to other countries. In foreign policy realm, China supports the maintenance of the peaceful conditions in the world. Meanwhile, in security realm, China shows that, currently, it is not pursuing hegemony. Rather, China is prioritizing its economic development. Through peaceful conditions, China can build its economic capacity.

The most important thing for China is creating stable condition for its economic development and not becoming a foe for other parties. With those methods, China wants to protect its national interest in economic, foreign policy and security by peaceful means.

\section{Bibliography}

\section{Books}

Bijian. Zheng. (2005) 'China's "Peaceful Rise" to Great-Power Status', Foreign Affairs, 84(5): 18-24.

C. Bergsten.Fred, B.G. (2006) China: the Balance Sheet: What the world Needs to Know about the Emerging Power. New York: Public Affairs.

Gill. B. (2007) Rising Star: China's New Security Diplomacy. Washington D.C.: Brooking Institution Press.

Goldstein. A. (2005) 'China's Changing Strategic Landscape', in Avery Goldstein, Rising to the Challenge: China's Grand Strategy and International Security, Stanford: Stanford University.
Kim. Samuel S. (ed) (1998) China and the World: Chinese Foreign Policy Faces the New Millenium. United Kingdom: Westview Press.

Yunling. Zhang and Tang Shibling. (2005) 'China's Regional Strategy', in David Shambaugh (ed.), Power Shift: China and Asia's New Security Dynamics, Berkeley: University of California Press.

\section{Journals}

China's Information Office of the State Council, China National Defense in 2002 (Accessed 23 October 2012).

Jisi, W. (2005) China Search for Stability with America, Foreign Affairs, 84(5):39-47

\section{Online Sources}

Brookes, P. and Ji Hye Sie (2006) China's Influence in Africa: Implications for the United States [Online]. Available from:

<http://www.heritage.org/Research/ AsiaandthePacific/bg1916.cfm> [Accessed 15 March 2012].

Hachigian, N. with W. Chen and C.Beddor, (2009) China's New Engagement in the International System [Online]. Available from: $<$ http://cdn.americanprogress.org/w p-

content/uploads/issues/2009/11/pdf /chinas_new_engagement.pdf $><$ http ://www.americanprogress.org/wpcon tent/uploads/issues/2009/11/pdf/chi nas_new_engagement.pdf $>$ [Accessed 10 February 2014].

Kompas, 7 September 2011. 